Azis, et al/Jurnal Ekonomi Syariah Teori dan Terapan Vol. 6 No. 8 Agustus 2019: 1644-1659; PENGUKURAN METODE RASIO INFORMASI, RASIO SORTINO DAN ROY SAFETY FIRST RATIO PADA KINERJA REKSADANA SAHAM SYARIAH PERIODE 2015-2017

\title{
PENGUKURAN METODE RASIO INFORMASI, RASIO SORTINO DAN ROY SAFETY FIRST RATIO PADA KINERJA REKSADANA SAHAM SYARIAH PERIODE 2015-20171
}

\author{
Nur Rohman Azis \\ Departemen Ekonomi Syariah - Fakultas Ekonomi dan Bisnis - Universitas Airlangga \\ Email: nur-r-a-11@feb.unair.ac.id
}

\begin{abstract}
Atina Shofawati
Departemen Ekonomi Syariah - Fakultas Ekonomi dan Bisnis - Universitas Airlangga Email: atina-o@feb.unair.ac.id
\end{abstract}

\begin{abstract}
:
The Objective of this research is to identify whether there is a different level performance of mutual funds in syariah shares among Information Ratio, Sortino Ratio, and Roy Safety First Ratio. This analysis using qualitative descriptive. In this case, the authority of money service website mentions there are 21 mutual funds in syariah shares could be taken as the sample of the analysis by using purposive sampling method. Verification result is done by One-way Anova test. The measurement result of the mutual fund in syariah shares uses the method Information Ratio provides 3 mutual funds in syariah shares are in positive performance in 2015 and 2017 and 5 mutual funds in syariah shares are in negative performance in 2016. It means there is a different performance result of mutual fund in syariah shares. The result Sortino ratio provides all of mutual fund share are in negative performance in all of year. It means there is no different performance result of mutual fund in syariah shares. The result Roy Safety First Ratio provides all of mutual funds in syariah shares are in negative performance in 2015, 2 mutual funds in syariah shares are in negative performance in 2016 and 4 mutual funds in syariah shares are in positive performance in 2017. It means there is no different performance result of mutual fund in syariah shares.
\end{abstract}

Keywords: Performace of mutual funds, Information Ratio, Sortino Ratio, Roy Safety First Ratio, Mutual Funds in Syariah Shares.

\section{PENDAHULUAN}

\section{Latar Belakang}

Pada era globalisasi sekarang ini, masyarakat dihadapkan kepada realitas dunia yang serba cepat dan canggih. Tak terkecuali didalamnya masalah ekonomi dan keuangan. Produk-produk baru dikembangkan untuk menarik dana dari masyarakat. Salah satu produk yang telah berkembang pesat di Indonesia adalah Reksadana yang diluar negeri dikenal dengan Unit Trust atau Mutual Fund. (Gunawan, dan Almira, 2006:2).

Investasi merupakan kegiatan muamalah yang sangat dianjurkan, karena dengan berinvestasi harta yang dimiliki menjadi lebih produktif dan juga mendatangkan manfaat bagi orang lain dan merupakan bentuk aktif dari ekonomi syariah. Dalam perspektif Islam, harta yang dimiliki oleh seorang muslim terdapat zakat yang harus dibagi kepada muslim lain yang membutuhkan. Jika harta tersebut

\footnotetext{
${ }^{1}$ Jurnal ini merupakan bagian dari skripsi Nur Rohman Azis, NIM: 041511 433082, yang diuji pada tanggal 25 Juni 2019.
} 
Azis, et al/Jurnal Ekonomi Syariah Teori dan Terapan Vol. 6 No. 8 Agustus 2019: 1644-1659; PENGUKURAN METODE RASIO INFORMASI, RASIO SORTINO DAN ROY SAFETY FIRST RATIO PADA KINERJA REKSADANA SAHAM SYARIAH PERIODE 2015-2017

didiamkan, maka lambat laun akan termakan oleh zakatnya. Salah satu hikmah dari zakat ini adalah mendorong setiap muslim untuk menginvestasikan hartanya agar bertambah

Reksadana menurut UU No.8 tahun 1995 pasal 1 ayat 27 reksadana didefinisikan sebagaiwadah yang dipergunakan untuk menghimpun dana dari masyarakat pemodal untuk selanjutnya diinvestasikan dalam portofolio efek oleh manajer investasi. Berdasarkan konsep tersebut, secara jelas bahwa reksadana merupakan kumpulan dana dari masyarakat yang diinvestasikan pada saham, obligasi deposito berjangka, pasar vang, dan sebagainya. Reksadana ini mempunyai sebutan yang berbeda-beda diberbagai negara, unit trust untuk Inggris dan mutual fund untuk Amerika Serikat (Gunawan, dan Almira, 2006:8).

Memilih reksadana yang akan memberikan pengembalian seperti yang diharapkan membutuhkan cara pandang dan analisa yang tepat karena dengan memilih reksadana yang tepat dan yang memiliki kinerja yang baik dapat memberikan tingkat pengembalian yang tinggi serta dapat memperkecil risiko dalam menginvestasikan dana di reksadana (Rudiyanto, 2013:180). Pertimbangan yang harus diperhatikan investor ketika berinvestasi pada reksadana umumnya adalah kinerja reksadana tersebut.
Pertimbangan lainnya risiko, besarnya biaya, tinggi rendahnya harga atau NAB/Unit, besarnya aset yang dikelola reksadana (ukuran reksadana), laporan investasi dan komunikasi dengan manajer investasi.

Berdasarkan pada teori pasar modal, beberapa ukuran kinerja portofolio sudah memasukkankan factor return dan risiko dalam perhitungannya. Beberapa ukuran kinerja portofolio yang sudah memasukkan faktor risiko adalah Indeks Sharpe, Indeks Treynor Dan Indeks Jensen (Tandelilin,2001:324). Pengukuran kinerja reksadana saham juga bisa menggunakan Metode Rasio Informasi, Rasio Sortino Dan Rasio Roy Safety First (Rudiyanto,2013:177).

Berdasarkan hasil uraian diatas dalam latar belakang permasalahan dan hasil penelitian terdahulu yang lebih bervariasi, sulit untuk mendeteksi seberapa besar perbedaan kinerja reksadana saham syariah. Hal tersebut memberikan peluang untuk melakukan penelitian lanjutan, untuk menguji konsistensi hasil penelitian sebelumnya dan memperoleh bukti empiris ada tidaknya perbedaan kinerja reksadana saham syariah dengan menggunakan metode penilaian kinerja yang berbeda.

\section{Rumusan Masalah}

Berdasarkan uraian latar belakang diatas, maka rumusan masalah yang dapat diajukan pada penelitian ini yaitu apakah ada perbedaan pada kinerja reksadana 
Azis, et al/Jurnal Ekonomi Syariah Teori dan Terapan Vol. 6 No. 8 Agustus 2019: 1644-1659; PENGUKURAN METODE RASIO INFORMASI, RASIO SORTINO DAN ROY SAFETY FIRST RATIO PADA KINERJA REKSADANA SAHAM SYARIAH PERIODE 2015-2017

saham syariah yang diukur dengan menggunakan Metode Rasio Informasi, Rasio Sortino dan Roy Safety First ?

\section{Tujuan Penelitian}

Penelitian ini bertujuan untuk menjawab rumusan masalah yaitu untuk mengetahui apakah ada perbedaan pada kinerja reksadana saham syariah yang diukur dengan menggunakan Metode Rasio Informasi, Rasio Sortino dan Roy Safety First.

\section{TINJAUAN PUSTAKA}

\section{Pengertian Investasi}

Menurut Ahim (Jones, 2004:

3)Wilayah investasi dapat melingkupi aktivitas yang sangat luas. Bentuk investasi dapat berbentuk investasi uang pada sertifikat, deposito, obligasi, dan saham atau rekasadana. Secara umum investasi dijelaskan sebagai komitmen atas dana yang diharapkan akan membawa keuntungan pada masa yang telah ditentukan kemudian hari.

\section{Dasar Keputusan Inverstasi}

Menurut Tandelilin (2001:6), dasar keputusan investasi terdiri dari tingkat return yang diharapkan, tingkat resiko, serta hubungan antara return dan resiko.

1. Return

Alasan utama orang untuk berinvestasi adalah untuk memperoleh keuntungan. Return yang diharapkan investor dari investasi yang dilakukannya merupakan kompensasi atas biaya kesempatan (opportunity cost) dan resiko penurunan daya beli akibat adanya pengaruh inflasi. Pada konteks manajemen investasi, perlu dibedakan antara return yang diharapkan (expected return) dan return yang terjadi (realized return). Return yang diharapkan merupakan tingkat return yang diantisipasi investor di masa yang akan datang, sedangkan return yang terjadi atau return aktual merupakan tingkat return yang diperoleh investor pada masa lalu. Antara tingkat return yang diharapkan dan tingkat return aktual yang diperoleh investor dari investasi yang dilakukan mungkin saja berbeda.

2. Risiko

Resiko bisa diartikan sebagai kemungkinan return aktual yang berbeda dengan return yang diharapkan. Pada ilmu ekonomi pada umumnya, dan dalam ilmu investasi pada khususnya terdapat asumsi bahwa investor adalah makhluk yang rasional. Investor yang rasional tentunya tidak akan menyukai ketidakpastian atau resiko.

\section{Sejarah dan Pengertian Reksadana}

Reksadana mulai dikenal pertama kali di Belgia pada tahun 1822, yang berbentuk reksa dana tertutup (closed end fund). Reksadana tersebut diciptakan untuk para investor kaya yang ingin berpartisipasi dalam portofolio utang-utang pemerintah yang memiliki keuntungan tinggi. Para 
Azis, et al/Jurnal Ekonomi Syariah Teori dan Terapan Vol. 6 No. 8 Agustus 2019: 1644-1659; PENGUKURAN METODE RASIO INFORMASI, RASIO SORTINO DAN ROY SAFETY FIRST RATIO PADA KINERJA REKSADANA SAHAM SYARIAH PERIODE 2015-2017

tahun 1860, reksadana menyebar ke Inggris dan Skotlandia dalam bentuk Unit Investment Trust dan pada tahun 1920 mulai dikenal di Amerika Serikat dengan nama Mutual Fund. Kata Mutual Fund menunjuk pada pemanfaatan fund yang dikelola untuk kepentingan bersama (mutual) (Widjaja \& Ramaniya, 2006:7).

Definisi reksadana menurut Widjaja dan Ramaniya (2006:7) adalahReksa dana merupakan suatu bentuk pemberian jasa yang didirikan untuk membantu investor yang ingin berpartisipasi dalam pasar modal tanpa adanya keterlibatan secara langsung dalam prosedur, administrasi, dan analisis dalam sebuah pasar modal.

\section{Kinerja}

Stephen Robbins mengungkapkan perngertian dari kinerja (performance) adalah hasil evaluasi pekerjaan yang dilakukan individu dibandingkan dengan kriteria yang telah ditetapkan bersama. (Robbins, 1996: 439). Kinerja adalah keberhasilan personil, tim, atau unit organisasi dalam mewujudkan sasaran strategik yang telah ditetapkan sebelumnya dengan perilaku yang diharapkan (Mulyadi, 2001: 337). Dapat disimpulkan Kinerja (performance) adalah gambaran tentang tingkat pencapaian pelaksanaan suatu individu, kegiatan, dan program kebijakan dalam proses mewujudkan sasaran, tujuan, misi dan visi organisasi yang telah disepakati bersama dalam suatu organisasi.

\section{Pengukuran Kinerja Reksadana}

Pengukuran suatu kinerja dari reksadana perlu memahami terlebih dahulu bahwa metode perhitungan yang dipilih harus dapat mengukur hasil investasi (return) yang dicapai serta memungkinkan investor untuk membandingkan hasil investasi tersebut dengan hasil yang dicapai tolok ukur, portofolio lainnya atau pengelola investasi lainnya. (Jogiyanto,2009:190).

Terdapat beberapa metode pengukuran kinerja reksadana. Tiga metode pengukuran diantaranya yang dapat digunakan manajer investasi untuk menghitung kinerja reksadana yaitu :

1. Rasio Informasi

Rasio Informasi adalah rasio yang mengukur konsistensi dari reksadana untuk menghasilkan return yang berbeda dari benchmark yang menjadi acuan. Semakin besar rasio informasi menunjukkan bahwa reksadana tersebut mampu secara dan dengan stabil mengalahkan benchmark (Rudiyanto,2013:182)

2. Rasio Sortino

Sebuah modifikasi dari rasio Sharpe yang membedakan volatilitas berbahaya dari volatilitas umum dengan menghitung standar deviasi dari return aset negatif, disebut penyimpangan downside. Rasio Sortino mengurangi tingkat bebas risiko pengembalian dari pengembalian 
Azis, et al/Jurnal Ekonomi Syariah Teori dan Terapan Vol. 6 No. 8 Agustus 2019: 1644-1659; PENGUKURAN METODE RASIO INFORMASI, RASIO SORTINO DAN ROY SAFETY FIRST RATIO PADA KINERJA REKSADANA SAHAM SYARIAH PERIODE 2015-2017

portofolio, dan kemudian membagi dengan deviasi downside. Rasio Sortino yang besar menunjukkan ada probabilitas rendah kerugian besar. Hal ini dihitung dengan menggunakan rumus sebagai berikut (Simforianus dan hutagaol, 2008:215).

3. Roy Safety First Ratio

Sebuah portofolio optimal adalah salah satu yang meminimalkan kemungkinan bahwa return portofolio akan jatuh di bawah ambang batas. Pada notasi probabilitas, jika RP adalah pengembalian portofolio, dan RL adalah threshold (return minimum yang dapat diterima), maka portofolio yang $P(R P<R L)$ diminimalkan akan menjadi portofolio optimal sesuai dengan kriteria keselamatan. Rasio Roy safety first membantu menghitung tingkat ini dengan memberikan jumlah standar deviasi antara tingkat yang diharapkan dan tingkat minimum yang dapat diterima, dengan jumlah yang lebih tinggi dianggap lebih aman. Diformulakan (Rudiyanto, 2013:177)

\section{Hipotesis}

Terdapat perbedaan pada kinerja reksadana saham syariah yang diukur dengan menggunakan Metode Rasio Informasi, Rasio Sortino dan Roy Safety First Ratio.

\section{Model Analisis}

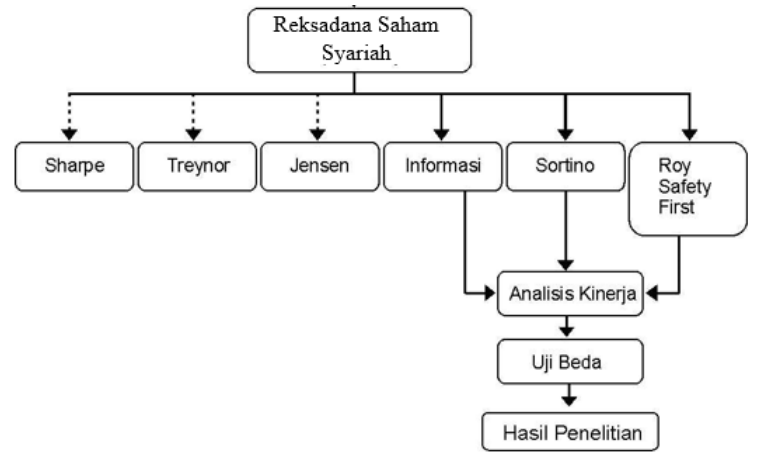

Gambar 1.

Model Analisis

Pada Penelitian ini, peneliti menggunakan tiga metode oleh manager investasi pada umumnya. Ketiga metode itu adalah Metode Rasio Informasi, Rasio Sortino dan Roy Safety First. Setelah itu tahap selanjutnya adalah uji dengan uji One-way Anova untuk mengetahui ada atau tidaknya perbedaan kinerja reksadana saham syariah periode 2015 2017 pada tiap metode pengukuran kinerja reksadana di atas.

\section{METODE PENELITIAN}

\section{Rancangan Penelitian}

Rancangan yang digunakan dalam penelitian ini adalah pendekatan kuantitatif. Berdasarkan pada latar belakang dan perumusan masalah yang telah divaraikan maka jenis penelitian ini adalah menggunakan penelitian kuantitif dengan pendekatan deskriptif, yaitu penelitian yang dilakukan untuk mengetahui nilai variabel mandiri, baik satu variabel atau lebih tanpa membuat perbandingan atau menghubungkan dengan variabel lain. 
Azis, et al/Jurnal Ekonomi Syariah Teori dan Terapan Vol. 6 No. 8 Agustus 2019: 1644-1659; PENGUKURAN METODE RASIO INFORMASI, RASIO SORTINO DAN ROY SAFETY FIRST RATIO PADA KINERJA REKSADANA SAHAM SYARIAH PERIODE 2015-2017

\section{Identifikasi Variabel}

Berdasarkan perumusan masalah dan tujuan penelitian maka penghitungan kinerja reksadana saham syariah menggunakan tiga metode penghitungan kinerja, yaitu Metode Informasi, Metode Sortino dan Metode Roy Safety First Ratio Pada Reksadana Saham Syariah periode $2015-2017$

\section{Definisi Operasional}

Definisi operasional adalah penjelasan definisi dari variabel yang telah dipilih oleh peneliti. Variabel-variabel yang digunakan dalam penelitian ini adalah:

1. Rasio Informasi

Rasio Informasi adalah rasio yang mengukur konsistensi dari reksadana untuk menghasilkan return yang berbeda dari benchmark yang menjadi acuan. Semakin besar rasio informasi menunjukkan bahwa reksadana tersebut mampu secara dan dengan stabil mengalahkan benchmark (Rudiyanto,2013:182)

IR $a \frac{\overline{\mathrm{R}} a-\overline{\mathrm{R}} m}{\sigma E R}$

(sumber: Jogiyanto,2010:664)

2. Rasio Sortino

Sebuah modifikasi dari rasio Sharpe yang membedakan volatilitas berbahaya dari volatilitas umum dengan menghitung standar deviasi dari return aset negatif, disebut penyimpangan downside. Rasio Sortino mengurangi tingkat bebas risiko pengembalian dari pengembalian portofolio, dan kemudian membagi dengan deviasi downside. Rasio Sortino yang besar menunjukkan ada probabilitas rendah kerugian besar. Hal ini dihitung dengan menggunakan rumus sebagai berikut (Simforianus dan hutagaol, 2008:215).

Rasio Sortino $=\frac{R_{a}-R_{f}}{\sigma_{d}}$

Menurut Ahmadinia (2012:216) adapun Downside deviation dapat dihitung dengan formula:

$D D=\sqrt{\frac{\sum(R r d-R f) 2}{N}}$, dimana $R r d<R f$

3. Roy Safety First Ratio

Sebuah portofolio optimal adalah salah satu yang meminimalkan kemungkinan bahwa return portofolio akan jatuh di bawah ambang batas. Pada notasi probabilitas, jika RP adalah pengembalian portofolio, dan RL adalah threshold (return minimum yang dapat diterima), maka portofolio yang $\mathrm{P}(\mathrm{RP}<\mathrm{RL})$ diminimalkan akan menjadi portofolio optimal sesuai dengan kriteria keselamatan. Rasio Roy safety first membantu menghitung tingkat ini dengan memberikan jumlah standar deviasi antara tingkat yang diharapkan dan tingkat minimum yang dapat diterima, dengan jumlah yang lebih tinggi dianggap lebih aman. Diformulakan (Rudiyanto, 2013:177) 
Azis, et al/Jurnal Ekonomi Syariah Teori dan Terapan Vol. 6 No. 8 Agustus 2019: 1644-1659; PENGUKURAN METODE RASIO INFORMASI, RASIO SORTINO DAN ROY SAFETY FIRST RATIO PADA KINERJA REKSADANA SAHAM SYARIAH PERIODE 2015-2017

$$
\text { Roys } \text { Ratio }=\frac{R \text { reksadana }-R \text { Diinginkan }}{S D \text { return reksadana }}
$$

\section{Jenis dan Sumber Data}

Data yang digunakan dalam penelitian ini adalah sekunder. Sumber data yang digunakan dalam penelitian ini diperoleh dari data NAB per unit masingmasing reksadana yang aktif terdaftar di Otoritas Jasa Keuangan (OJK) selama periode tahun 2015 sampai dengan 2017 yang diperoleh dari Otoritas Jasa Kevangan (OJK) yaitu http://www.ojk.go.id

\section{Populasi dan Sampel}

Populasi dalam penelitian ini adalah perusahaan reksadana syariah saham yang terdaftar di OJK dan memperoleh penyertaan efektif dari OJK selama periode 2015-2017. Berdasarkan kriteria, sampel yang telah ditentukansebelumnya dari Januari 2015 sampai dengan Desember 2017. Maka yang masuk kriteriasampel hanya 21 produk reksadana saham syariah. Metode pengambilan sampel yang digunakan adalah metode purposivesampling.

Tabel 1. Sampel Reksadana Saham Syariah

\begin{tabular}{|r|l|c|}
\hline No & \multicolumn{1}{|c|}{ Nama Produk Reksadana } & Variabel \\
\hline 1 & Trim Syariah Saham & N1 \\
\hline 2 & Batavia Dana Saham Syriah & N2 \\
\hline 3 & Pnm Ekuitas Syariah & N3 \\
\hline 4 & $\begin{array}{l}\text { Gimb-Principal Islamic Equity } \\
\text { N4 }\end{array}$ & \\
\hline 6 & Mandiri Investa Atraktif Syariah & N5 \\
\hline 7 & Manulife Syariah Sektoral Amanah & N8 \\
\hline 8 & Panin Dana Syariah Saham & N8 \\
\hline 9 & Mnc Dana Syariah Ekuitas & N9 \\
\hline 10 & Sam Sharia Equity Fund & N10 \\
\hline 11 & Lautandhana Saham Syariah & N11 \\
\hline
\end{tabular}

\begin{tabular}{|c|l|c|}
\hline 12 & Mandiri Investa Ekuitas Syariah & $\mathrm{N} 12$ \\
\hline 13 & Oso Syariah Equity Fund & $\mathrm{N} 13$ \\
\hline 14 & Avrist Equity 'Amar Syariah & $\mathrm{N} 14$ \\
\hline 15 & Sucorinvest Sharia Equity Fund & $\mathrm{N} 15$ \\
\hline 16 & Danareksa Syariah Saham & $\mathrm{N} 16$ \\
\hline 17 & Hpam Syariah Ekuitas & $\mathrm{N} 17$ \\
\hline 18 & Simas Syariah Berkembang & $\mathrm{N} 18$ \\
\hline 19 & Simas Syariah Unggulan & $\mathrm{N} 19$ \\
\hline 20 & Pratama Syariah & $\mathrm{N} 20$ \\
\hline 21 & Pacific Saham Syariah & $\mathrm{N} 21$ \\
\hline
\end{tabular}

Teknik Analisis

Metode analisis data yang digunakan dalam penelitian ini adalah menggunakan analisis kuantitatif dengan menggunakandata time series. Analisis yang digunakan dalam pengukuran kinerja reksadana syariah pendapatan tetap adalah metode rasio informasi, metode sortino dan metode roy safety first.

Untuk mempermudah perhitungan diatas maka yang diperlukan variabel pendukung seperti:

1. $N A B$ (Nilai Aktiva Bersih)

NAB merupakan salah satu tolak ukur untuk menilai kinerja reksadana, NAB yang digunaan merupakan NAB 21 reksadana syariah dari kategori saham yang telah terpilih sebagai obyek penelitian yang masuk dalam penelitian. Data NAB reksadana didapatkan dari akses www.kontan.co.id

2. SBI (Surat Bank Indonesia)

SBI sebagai asset investasi yang bebas resiko karena dikelola oleh pemerintah maka kemungkinan gagal bayar bisa dikatakan kecil sekali dan tingkat pengembaliannya sudah dapat 
Azis, et al/Jurnal Ekonomi Syariah Teori dan Terapan Vol. 6 No. 8 Agustus 2019: 1644-1659; PENGUKURAN METODE RASIO INFORMASI, RASIO SORTINO DAN ROY SAFETY FIRST RATIO PADA KINERJA REKSADANA SAHAM SYARIAH PERIODE 2015-2017

dipastikan. Pada penelitian digunakan untuk variabel pengembalian yang bebas resiko. www.bi.go.id

3. JII ( Jakarta Islamic Index )

Merupakan representasi nilai tingkat pengembalian portofolio pasar yang masuk dalam 30 saham pada indeks Jakarta Islamic Index (JII). Tingkat pengembalian portofolio yang tergabung dalam Jakarta Islamic Index (JII) digunakan untuk acuan return benchmark pada penelitian ini.

4. IHSG

Nilai tingkat pengembalian portofolio pasar yang masuk dalam indeks harga saham gabungan atau IHSG (Rudiyanto, 2013:191). Tingkat pengembalian portofolio pasar yang masuk dalam indeks harga saham gabungan atau IHSG digunakan untuk variable pengembalian yang diinginkan oleh manajer investasi.

\section{Uji F-Statistik One-Way Anova}

Uji f One-way Anova adalah pengujian model secara keseluruhan. Uji ini dilakukan untuk membuktikan apakah ada perbedaan kinerja reksdana saham syariah periode 2015-2017 dengan masing-masing metode pengkuran kinerja. Pengujian dilakukan dengan menggunakan significance level 0,05 ( $a=5 \%)$.

\section{Uji Tukey}

Uji Tukey adalah pengujian model secara mandiri/parsial. Uji ini dilakukan untuk mengetahui perbedaan kinerja reksdana saham pada suatu tahun tertentu terhadap tahun yang lain. Pengujian dilakukan dengan menggunakan significance level 0,05 ( $a=5 \%)$.

\section{HASIL PENELITIAN DAN PEMBAHASAN}

Pengukuran Kinerja Reksada Saham Syariah Rasio Informasi

Pada pengukuran Rasio Informasi diketahui return benchmark JII periode 2015 - 2017 berturut adalah $-0.0106,0.0105$, dan 0.0091 . Hasil pengukuran reksadana saham dengan Rasio Informasi menunjukkan hasil sebagai berikut:

Tabel 2.

Hasil Pengukuran Metode Rasio Informasi

\begin{tabular}{|c|c|c|c|c|}
\hline No & Variabel & 2015 & 2016 & 2017 \\
\hline 1 & $\mathrm{~N} 1$ & -0.163 & -0.010 & -0.413 \\
\hline 2 & $\mathrm{~N} 2$ & -0.080 & -0.065 & 0.153 \\
\hline 3 & $\mathrm{~N} 3$ & -0.626 & -0.068 & -0.324 \\
\hline 4 & $\mathrm{~N} 4$ & -0.249 & -0.095 & -0.413 \\
\hline 5 & $\mathrm{~N} 5$ & -0.124 & -0.068 & -0.514 \\
\hline 6 & $\mathrm{~N} 7$ & -0.066 & -0.099 & -0.339 \\
\hline 7 & $\mathrm{~N} 8$ & -0.066 & 0.034 & -0.490 \\
\hline 8 & $\mathrm{~N} 8$ & 0.014 & -0.040 & -0.474 \\
\hline 9 & $\mathrm{~N} 9$ & -0.138 & -0.017 & -0.461 \\
\hline 10 & $\mathrm{~N} 10$ & -0.188 & -0.287 & -0.728 \\
\hline No & Variabel & 2015 & 2016 & 2017 \\
\hline 11 & $\mathrm{~N} 11$ & -0.127 & -0.133 & -0.386 \\
\hline 12 & $\mathrm{~N} 12$ & -0.093 & -0.073 & -0.408 \\
\hline 13 & $\mathrm{~N} 13$ & -0.128 & -0.189 & -0.891 \\
\hline 14 & $\mathrm{~N} 14$ & -0.107 & -0.103 & -0.508 \\
\hline 15 & $\mathrm{~N} 15$ & -0.291 & 0.655 & 0.375 \\
\hline 16 & $\mathrm{~N} 16$ & -0.014 & -0.080 & -0.525 \\
\hline 17 & $\mathrm{~N} 17$ & -0.085 & 0.171 & -0.084 \\
\hline 18 & $\mathrm{~N} 18$ & 0.116 & 0.247 & -0.853 \\
\hline 19 & $\mathrm{~N} 19$ & -0.286 & 0.244 & -0.744 \\
\hline 20 & $\mathrm{~N} 20$ & -0.007 & -0.098 & -0.308 \\
\hline 21 & $\mathrm{~N} 21$ & 0.308 & -0.223 & 0.236 \\
\hline
\end{tabular}

\section{Rasio Sortino}

Pada pengukuran Rasio Sortino menggunakan return bebas resiko periode 
Azis, et al/Jurnal Ekonomi Syariah Teori dan Terapan Vol. 6 No. 8 Agustus 2019: 1644-1659; PENGUKURAN METODE RASIO INFORMASI, RASIO SORTINO DAN ROY SAFETY FIRST RATIO PADA KINERJA REKSADANA SAHAM SYARIAH PERIODE 2015-2017

2015 - 2017 berturut adalah 0.0752, 0.0595,

dan 0.0456. Pengukuran reksadana saham dengan Rasio Informasi menggunkan model Downside Deviation yaitu konsep dimana nilai tingkat pengembalian dibawah nilai pengembalian bebas resiko dianggap sebagai resiko.

Rekap hasil perhitungan downside deviaton reksadana saham syariah periode 2015-2017 sebagai berikut :

Tabel 3.

Hasil Perhitungan Downside Deviation

\begin{tabular}{|r|c|c|c|c|}
\hline No & Variabel & 2015 & 2016 & 2017 \\
\hline 1 & $\mathrm{~N} 1$ & 0.0358 & 0.0361 & 0.0184 \\
\hline 2 & $\mathrm{~N} 2$ & 0.0365 & 0.0306 & 0.0159 \\
\hline 3 & $\mathrm{~N} 3$ & 0.0290 & 0.0344 & 0.0209 \\
\hline 4 & $\mathrm{~N} 4$ & 0.0425 & 0.0356 & 0.0214 \\
\hline 5 & $\mathrm{~N} 5$ & 0.0392 & 0.0345 & 0.0192 \\
\hline 6 & $\mathrm{~N} 7$ & 0.0389 & 0.0345 & 0.0246 \\
\hline 7 & $\mathrm{~N} 8$ & 0.0415 & 0.0374 & 0.0184 \\
\hline 8 & $\mathrm{~N} 8$ & 0.0522 & 0.0324 & 0.0199 \\
\hline 9 & $\mathrm{~N} 9$ & 0.0424 & 0.0318 & 0.0117 \\
\hline 10 & $\mathrm{~N} 10$ & 0.0577 & 0.0411 & 0.0287 \\
\hline 11 & $\mathrm{~N} 11$ & 0.0439 & 0.0327 & 0.0196 \\
\hline 12 & $\mathrm{~N} 12$ & 0.0421 & 0.0354 & 0.0199 \\
\hline 13 & $\mathrm{~N} 13$ & 0.0466 & 0.0544 & 0.0290 \\
\hline 14 & $\mathrm{~N} 14$ & 0.0519 & 0.0366 & 0.0200 \\
\hline 15 & $\mathrm{~N} 15$ & 0.0501 & 0.0287 & 0.0242 \\
\hline 16 & $\mathrm{~N} 16$ & 0.0408 & 0.0321 & 0.0209 \\
\hline $\mathrm{No}$ & Variabel & 2015 & 2016 & 2017 \\
\hline 17 & $\mathrm{~N} 17$ & 0.0464 & 0.0296 & 0.0359 \\
\hline 18 & $\mathrm{~N} 18$ & 0.0386 & 0.0257 & 0.0099 \\
\hline 19 & $\mathrm{~N} 19$ & 0.0454 & 0.0401 & 0.0186 \\
\hline 20 & $\mathrm{~N} 20$ & 0.0612 & 0.0385 & 0.0343 \\
\hline 21 & $\mathrm{~N} 21$ & 0.0346 & 0.0591 & 0.0537 \\
\hline
\end{tabular}

Hasil pengukuran kinerja reksadana saham syariah periode 2015-2017 menggunakan Rasio Sortino dengan pengembalian bebas resiko dan downside deviation diatas adalah sebagai berikut:

Tabel 4.

Hasil Pengukuran Metode Rasio Sortino

\begin{tabular}{|r|c|c|c|c|}
\hline No & Variabel & 2015 & 2016 & 2017 \\
\hline 1 & $\mathrm{~N} 1$ & -1.0082 & -0.9729 & -0.9820 \\
\hline 2 & $\mathrm{~N} 2$ & -0.9764 & -1.0047 & -0.7589 \\
\hline 3 & $\mathrm{~N} 3$ & -1.1442 & -1.0118 & -0.9644 \\
\hline 4 & $\mathrm{~N} 4$ & -1.0603 & -1.0325 & -1.0100 \\
\hline 5 & $\mathrm{~N} 5$ & -0.9978 & -1.0115 & -1.0323 \\
\hline 6 & $\mathrm{~N} 7$ & -0.9725 & -1.0330 & -0.9989 \\
\hline 7 & $\mathrm{~N} 8$ & -0.9743 & -0.9403 & -1.0144 \\
\hline 8 & $\mathrm{~N} 8$ & -0.9359 & -0.9913 & -1.0229 \\
\hline 9 & $\mathrm{~N} 9$ & -1.0088 & -0.9761 & -0.9330 \\
\hline 10 & $\mathrm{~N} 10$ & -1.0635 & -1.1982 & -1.2787 \\
\hline 11 & $\mathrm{~N} 11$ & -1.0056 & -1.0514 & -0.9812 \\
\hline 12 & $\mathrm{~N} 12$ & -0.9872 & -1.0167 & -0.9942 \\
\hline 13 & $\mathrm{~N} 13$ & -1.0097 & -1.1684 & -1.3885 \\
\hline 14 & $\mathrm{~N} 14$ & -1.0054 & -1.0396 & -1.0398 \\
\hline 15 & $\mathrm{~N} 15$ & -1.1044 & -0.5946 & -0.6113 \\
\hline 16 & $\mathrm{~N} 16$ & -0.9503 & -1.0164 & -1.0573 \\
\hline 17 & $\mathrm{~N} 17$ & -0.9877 & -0.8659 & -0.8803 \\
\hline 18 & $\mathrm{~N} 18$ & -0.8950 & -0.8402 & -1.0012 \\
\hline 19 & $\mathrm{~N} 19$ & -1.0870 & -0.7725 & -1.1208 \\
\hline 20 & $\mathrm{~N} 20$ & -0.9491 & -1.0402 & -1.0478 \\
\hline 21 & $\mathrm{~N} 21$ & -0.8267 & -1.2258 & -0.5311 \\
\hline
\end{tabular}

Roy Safety First Ratio

Pada penghitungan ini, diasumsikan tingkat pengembalian minimal yang dinginkan oleh investor adalah sama dengan rata - rata return bulanan IHSG selama periode 2015-2017 yaitu sebesar 0.0058 atau $0.58 \%$. Angka ini dipilih sebagai dasar bahwa reksadana saham syariah merupakan jenis reksadana baru sehingga tingkat pengembalian yang diinginkanpun juga tidak harus tinggi namun terukur.

Tabel 5.

Hasil Pengukuran Metode Roy Safety First

\begin{tabular}{|r|c|c|c|c|}
\hline No & Variabel & 2015 & 2016 & 2017 \\
\hline 1 & $\mathrm{~N} 1$ & -0.1627 & -0.0103 & -0.4132 \\
\hline 2 & $\mathrm{~N} 2$ & -0.0803 & -0.0647 & 0.1533 \\
\hline 3 & $\mathrm{~N} 3$ & -0.6262 & -0.0681 & -0.3243 \\
\hline 4 & $\mathrm{~N} 4$ & -0.2485 & -0.0953 & -0.4125 \\
\hline 5 & $\mathrm{~N} 5$ & -0.1243 & -0.0675 & -0.5137 \\
\hline 6 & $\mathrm{~N} 7$ & -0.0663 & -0.0990 & -0.3391 \\
\hline 7 & $\mathrm{~N} 8$ & -0.0659 & 0.0342 & -0.4904 \\
\hline 8 & $\mathrm{~N} 8$ & 0.0144 & -0.0403 & -0.4740 \\
\hline 9 & $\mathrm{~N} 9$ & -0.1384 & -0.0167 & -0.4610 \\
\hline 10 & $\mathrm{~N} 10$ & -0.1880 & -0.2872 & -0.7281 \\
\hline
\end{tabular}


Azis, et al/Jurnal Ekonomi Syariah Teori dan Terapan Vol. 6 No. 8 Agustus 2019: 1644-1659; PENGUKURAN METODE RASIO INFORMASI, RASIO SORTINO DAN ROY SAFETY FIRST RATIO PADA KINERJA REKSADANA SAHAM SYARIAH PERIODE 2015-2017

\begin{tabular}{|r|r|r|r|r|}
\hline 11 & $\mathrm{~N} 11$ & -0.1273 & -0.1332 & -0.3861 \\
\hline 12 & $\mathrm{~N} 12$ & -0.0930 & -0.0732 & -0.4078 \\
\hline 13 & $\mathrm{~N} 13$ & -0.1278 & -0.1893 & -0.8915 \\
\hline 14 & $\mathrm{~N} 14$ & -0.1073 & -0.1027 & -0.5079 \\
\hline 15 & $\mathrm{~N} 15$ & -0.2907 & 0.6548 & 0.3753 \\
\hline 16 & $\mathrm{~N} 16$ & -0.0138 & -0.0802 & -0.5250 \\
\hline 17 & $\mathrm{~N} 17$ & -0.0854 & 0.1707 & -0.0839 \\
\hline 18 & $\mathrm{~N} 18$ & 0.1158 & 0.2475 & -0.8527 \\
\hline 19 & $\mathrm{~N} 19$ & -0.2860 & 0.2443 & -0.7437 \\
\hline 20 & $\mathrm{~N} 20$ & -0.0074 & -0.0983 & -0.3076 \\
\hline 21 & $\mathrm{~N} 21$ & 0.3085 & -0.2234 & 0.2361 \\
\hline
\end{tabular}

Uji Hipotesis

Uji Hipotesis ini menggunakan uji Oneway Anovadigunakan untuk menguji ada atau tidaknya perbedaan kinerja reksadana periode 2015 - 2017 berdasarkan tiga metode yang telah diteliti pada bagian - bagian sebelumnya, dimana:

$\mathrm{H}_{0}$ : Tidak terdapat perbedaan kinerjareksadana saham syariah selama periode 2015 sampai dengan 2017

$\mathrm{H}_{1}$ : Terdapat perbedaan kinerja reksadana saham syariah selama periode 2015 sampai dengan 2017

Kriteria dalam penerimaan $\mathrm{HO}$ dan $\mathrm{H} \mathrm{l}$ adalah dengan melihat nilai probabilitas statistik F. Jika nilai probabilitas lebih kecil dari 0,05 (taraf kepercayaan 95\%) maka HO ditolak dan $\mathrm{H} 1$ diterima.

\section{Uji One-way Anova Pada Hasil Pengukuran Metode Rasio Informasi}

Tabel 6.

Hasil Uji ANOVA Rasio Informasi

\begin{tabular}{lcrlcrr}
\hline \multicolumn{1}{c}{$\begin{array}{c}\text { Source of } \\
\text { Variation }\end{array}$} & \multicolumn{1}{c}{$S S$} & \multicolumn{1}{c}{$d f$} & MS & $F$ & $\begin{array}{c}\text { P- } \\
\text { value }\end{array}$ & F crit \\
\hline Between Groups & 1.551 & 2 & 0.775 & 12.88 & 0.00 & 3.15 \\
Within Groups & 3.610 & 60 & 0.060 & & & \\
& & & & & & \\
Total & 5.161 & 62 & & & & \\
\hline
\end{tabular}

Dari hasil uji One-way Anova dapat diketahui terdapat perbedaan terhadap kinerja reksadana saham syariah periode 2015 hingga 2017 dengan menggunakan metode rasio informasi. Dimana, nilai untuk F hitung adalah 12.89 dengan probabilitas 0.00. Sedangkan untuk nilai $F$ statistik dengan probabilitas 0,05 adalah 3.15. Maka hal ini menyimpulkan bahwa $F$ hitung $>F$ tabel $(12.89>3.15)$. Posisi F hitung berada pada sisi penolakan atas $\mathrm{HO}$

Tabel 7.

Tukey Simultaneous Tests for Differences of Means

\begin{tabular}{lrr}
$\begin{array}{l}\text { Difference } \\
\text { of Levels }\end{array}$ & $\begin{array}{r}\text { Difference } \\
\text { of Means }\end{array}$ & $\begin{array}{r}\text { SE o } \\
\text { Difference }\end{array}$ \\
\hline $2016-2015$ & 0.1001 & 0.0757 \\
$2017-2015$ & -0.2713 & 0.0757 \\
$2017-2016$ & -0.3714 & 0.0757
\end{tabular}

Perbedaan kinerja reksadana saham syariah tersebut setelah di analisis dengan Uji Tukey mendapatkan hasil bahwa kinerja tahun 2017 berbeda signifikan jika dibandingkan dengan kinerja reksadana saham syariah tahun 2015 dan 2016. Sedangkan, pada tahun 2015 dan 2016

\begin{tabular}{crr}
$95 \%$ CI & T-Value & $\begin{array}{r}\text { Adjusted } \\
\text { P-Value }\end{array}$ \\
\hline$(-0.0819,0.2821)$ & 1.32 & 0.388 \\
$(-0.4533,-0.0893)$ & -3.58 & 0.002 \\
$(-0.5534,-0.1894)$ & -4.91 & 0.000
\end{tabular}
kinerja reksadana saham menunjukkan hasil perbedaan yang tidak signifikan atau tidak ada perbedaan kinerja pada 2015 dan 2016.

Uji One-way Anova Pada Hasil Pengukuran

\section{Metode Rasio Sortino}

Tabel 8.

Hasil Uji ANOVA Rasio Sortino 
Azis, et al/Jurnal Ekonomi Syariah Teori dan Terapan Vol. 6 No. 8 Agustus 2019: 1644-1659; PENGUKURAN METODE RASIO INFORMASI, RASIO SORTINO DAN ROY SAFETY FIRST RATIO PADA KINERJA REKSADANA SAHAM SYARIAH PERIODE 2015-2017

\begin{tabular}{lcrlcrr}
\hline \multicolumn{1}{c}{$\begin{array}{c}\text { Source of } \\
\text { Variation }\end{array}$} & SS & \multicolumn{1}{c}{$d f$} & MS & $F$ & $\begin{array}{c}P \text { - } \\
\text { value }\end{array}$ & F crit \\
\hline Between Groups & 0.002 & 2 & 0.001 & 0.055 & 0.95 & 3.15 \\
Within Groups & 1.186 & 60 & 0.020 & & &
\end{tabular}

\begin{tabular}{ccc} 
Total & 1.188 & \\
\hline Dari hasil uji & One-way Anova dapat
\end{tabular}

diketahui bahwa secara bersama-sama tidak terdapat perbedaan terhadap kinerja reksadana saham syariah periode 2015 hingga 2017 dengan menggunakan metode Rasio Sortino. Pada Uji ini nilai untuk F hitung adalah 0.054 dengan probabilitas 0.946. Sedangkan untuk nilai F tabel dengan probabilitas 0,05 adalah 3.15. Maka hal ini menyimpulkan bahwa pada uji ANOVA $F$ hitung < F tabel $(0.95<3.15)$.

Hasil uji di atas dapat disimpulkan posisi $F$ hitung berada pada sisi penerimaan atas HO. Dapat ditarik kesimpulan bahwa pada uji One-way Anova tidak terdapat perbedaan pada penghitungan kinerja reksadana saham syariah periode 2015 hingga 2017 dengan metode Rasio Sortino.
Uji One-way Anova Pada Hasil Pengukuran Metode Roy Safety First Ratio

Tabel 9. Hasil Uji ANOVA

\begin{tabular}{lcccccc}
\hline \multicolumn{1}{c}{$\begin{array}{c}\text { Source of } \\
\text { Variation }\end{array}$} & SS & $d f$ & MS & $F$ & $\begin{array}{c}\text { P- } \\
\text { value }\end{array}$ & F crit \\
\hline Between Groups & 4.079 & 2 & 2.040 & 33.05 & 0.00 & 3.15 \\
Within Groups & 3.702 & 60 & 0.062 & & & \\
& & & & & & \\
Total & 7.781 & 62 & & & & \\
\hline
\end{tabular}

Hasil Uji One-way Anova dapat diketahui bahwa terdapat perbedaan terhadap kinerja reksadana saham syariah periode 2015 hingga 2017 dengan menggunakan metode Roy Safety First Ratio. Dimana, nilai untuk $F$ hitung adalah 33.05 dengan signifikansi 0.00 . Sedangkan untuk nilai $F$ tabel dengan signifikansi 0,05 adalah 3.15. Maka hal ini menyimpulkan bahwa $\mathrm{F}$ hitung $>$ F tabel $(33.05>3.15)$. Hasil uji posisi $F$ hitung berada pada sisi penolakan atas $\mathrm{HO}$. Dapat ditarik kesimpulan bahwa terdapat perbedaan pada penghitungan kinerja reksadana saham syariah periode 2015 hingga 2017 dengan metode Roy Safety First Ratio.

Tabel 10.

Tukey Simultaneous Tests for Differences of Means

\begin{tabular}{|c|c|c|c|c|c|}
\hline $\begin{array}{l}\text { Difference } \\
\text { of Levels }\end{array}$ & $\begin{array}{r}\text { Difference } \\
\text { of Means }\end{array}$ & $\begin{array}{r}\text { SE of } \\
\text { Difference }\end{array}$ & $95 \% \mathrm{CI}$ & T-Value & $\begin{array}{c}\text { Adjusted } \\
\text { P-Value }\end{array}$ \\
\hline $2016-2015$ & 0.6221 & 0.0757 & $(0.4377,0.8064)$ & 8.11 & 0.000 \\
\hline $2017-2015$ & 0.2768 & 0.0757 & $(0.0925,0.4611)$ & 3.61 & 0.002 \\
\hline $2017-2016$ & 0.3452 & 0.0757 & $(-0.5296,-0.1609)$ & -4.50 & 0.000 \\
\hline
\end{tabular}

Perbedaan kinerja reksadana saham syariah tersebut setelah di analisis dengan Uji Tukey mendapatkan hasil bahwa kinerja tiap tahun berbeda signifikan jika dibandingkan dengan kinerja reksadana saham syariah tahun lainnya.

\section{PEMBAHASAN}

1. Kinerja Metode Informasi Periode 2015-2017

Pada tahun 2015 diketahui return benchmark sebesar -0.01064 berdasarkan 
Azis, et al/Jurnal Ekonomi Syariah Teori dan Terapan Vol. 6 No. 8 Agustus 2019: 1644-1659; PENGUKURAN METODE RASIO INFORMASI, RASIO SORTINO DAN ROY SAFETY FIRST RATIO PADA KINERJA REKSADANA SAHAM SYARIAH PERIODE 2015-2017

rata-rata return JII tahun 2015. Pada pengukuran kinerja reksadana saham syariah menggunakan metode Informasi didapatkan mayoritas produk reksadana saham syariah yang memiliki kinerja negatif. Hanya 3 produk reksadana yang memiliki kinerja positif. Ketiga produk reksadana saham ini pada tahun 2015 mempunyai rata-rata return bulanan lebih tinggi dari pada rata-rata return bulanan JII pada tahun yang sama.

Pada perhitungan kinerja reksadana saham syariah tahun 2016, diketahui ratarata return benchmark pada tahun 2016 ditentukan sebesar 0.010512 berdasarkan data return JII tahun 2016. Pada tahun 2016 rata-rata return bulanan JII mengalami kenaikan sebesar 0.02115 dibandingkan tahun sebelumnya. Pada tahun 2016 kinerja reksadana saham syariah masih didominasi dengan hasil penilain kinerja yang negatif seperti tahun 2015. Hanya ada 5 produk reksadana dengan hasil penilaian yang menunjukkan angka positif.

Pada perhitungan kinerja reksadana saham syariah tahun 2017, rata-rata return benchmark pada tahun 2017 ditentukan sebesar 0.009077 berdasarkan data return JII tahun 2017. Rata - rata return JII mengalami penurunan sebesar 0.001436 dibandingkan return JII pada tahun 2016. Pada pengukuran kinerja reksadana saham syariah menggunakan metode Informasi didapatkan mayoritas produk reksadana saham syariah yang memiliki kinerja negatif. Seperti halnya tahun 2015 hanya 3 produk reksadana yang memiliki kinerja positif.

Hasil uji One-Way Anova menyatakan bahwa nilai $\mathrm{F}$ hitung lebih dari $\mathrm{F}$ tabel dimana posisi $\mathrm{F}$ hitung berada pada sisi penolakan atas HO. Dapat ditarik kesimpulan bahwa terdapat perbedaan pada penghitungan kinerja reksadana saham syariah periode 2015 hingga 2017 dengan metode Informasi. Perbedaan kinerja reksadana saham syariah tersebut setelah di analisis dengan Uji Tukey mendapatkan hasil bahwa kinerja tahun 2017 berbeda signifikan jika dibandingkan dengan kinerja reksadana saham syariah tahun 2015 dan 2016. Sedangkan, pada tahun 2015 dan 2016 kinerja reksadana saham menunjukkan hasil perbedaan yang tidak signifikan atau tidak ada perbedaan kinerja pada 2015 dan 2016.

\section{Kinerja Metode Sortino Periode 2015-2017}

Pada tahun 2015 diketahui rata-rata suku bunga bebas resiko sebesar 0.075208 dan downside deviation sebesar 0.090919.Pada pengukuran kinerja reksadana saham syariah tahun 2015 menggunakan Metode Sortino didapatkan seluruh produk reksadana saham syariah yang memiliki penilaian kinerja yang negatif.

Pada tahun 2016 diketahui rata-rata return bebas resiko sebesar 0.059483 turun sebesar 0.015725 dibandingkan tahun 
Azis, et al/Jurnal Ekonomi Syariah Teori dan Terapan Vol. 6 No. 8 Agustus 2019: 1644-1659; PENGUKURAN METODE RASIO INFORMASI, RASIO SORTINO DAN ROY SAFETY FIRST RATIO PADA KINERJA REKSADANA SAHAM SYARIAH PERIODE 2015-2017

sebelumnya dan downside deviation sebesar 0.050718. Sama halnya pada tahun 2015, pada pengukuran kinerja reksadana saham syariah menggunakan Metode Sortino tahun 2016 didapatkan seluruh produk reksadana saham syariah yang memiliki penilaian kinerja yang negatif.

Pada tahun 2017 diketahui rata-rata return bebas resiko sebesar 0.045625 turun sebesar 0.013858 dibandingkan tahun sebelumnya dan downside deviation sebesar 0.044942. Pada tahun 2017 seluruh kinerja reksadana saham syariah masih menunjukkan hasil penilain kinerja yang negatif seperti tahun 2015 dan 2016.

Hasil uji One-way Anova dapat disimpulkan bahwa nilai $F$ hitung kurang dari $F$ tabel. dimana posisi $F$ hitung berada pada sisi penerimaan atas HO. Dapat ditarik kesimpulan bahwa pada uji ANOVA tidak terdapat perbedaan pada penghitungan kinerja reksadana saham syariah periode 2015 hingga 2017 dengan metode Rasio Sortino.

\section{Kinerja Metode Roy Safety First Ratio} Periode 2015-2017

Pada penilaian ini, diasumsikan ratarata tingkat pengembalian minimal yang dinginkan oleh investor adalah sama dengan rata - rata return bulanan IHSG selama tiga tahun yaitu periode 2015-2017 yaitu sebesar 0.0058 atau $0.58 \%$. Pada pengukuran kinerja tahun 2015 menggunakan rasio ini didapati hasil yang keseluruhan mendapatkan penilaian negatif. Hal ini dikarenakan rata-rata tingkat pengembalian reksadana saham syariah pada kenyataannya masih dibawah nilai rata-rata tingkat pengembalian yang diinginkan oleh investor sebesar 0.0058 .

Pada tahun 2016 kinerja reksadana saham syariah mayoritas menunjukan hasil penilaian yang positif. Pada tahun ini terdapat tiga reksadana yang menunjukkan penilaian kinerja yang negatif.

Selama tahun 2017 kinerja reksadana saham syariah mayoritas menunjukan kembali trend penilaian yang negatif. Pada tahun tersebut hanya terdapat empat reksadana menunjukkan penilaian kinerja yang positif.

Kesimpulan dari pengukuran kinerja reksadana saham syariah menggunakan rasio roy safety first adalah nilai rata-rata tingkat pengembalian suatu reksadana saham syariah apabila investor menginginkan tingkat pengembalian yang lebih tinggi maka hasil dari pengkuran menggunakan metode ini akan selalu menunjukkan nilai yang negatif begitupun sebaliknya berapaun rata-rata tingkat pengembalian suatu reksadana saham syariah jika investor menerima atau menginginkan tingkat pengembalian yang ternyata di bawah tingkat pengembalian yang sebenarnya dimiliki oleh reksadana saham syariah tersebut maka hasil pengukuran menggunakan metode Roy 
Azis, et al/Jurnal Ekonomi Syariah Teori dan Terapan Vol. 6 No. 8 Agustus 2019: 1644-1659; PENGUKURAN METODE RASIO INFORMASI, RASIO SORTINO DAN ROY SAFETY FIRST RATIO PADA KINERJA REKSADANA SAHAM SYARIAH PERIODE 2015-2017

safety first ini akan menunjukkan bahwa kinerja reksadana saham syariah tersebut baik.

Hasil uji One-way Anova menyatakan bahwa nilai $\mathrm{F}$ hitung lebih dari $\mathrm{F}$ tabel dimana posisi $\mathrm{F}$ hitung berada pada sisi penolakan atas HO. Dapat ditarik kesimpulan bahwa terdapat perbedaan pada penghitungan kinerja reksadana saham syariah periode 2015 hingga 2017 dengan metode Roy Safety First Ratio. Perbedaan kinerja reksadana saham syariah tersebut setelah di analisis dengan Uji Tukey mendapatkan hasil bahwa kinerja tiap tahun berbeda signifikan jika dibandingkan dengan kinerja reksadana saham syariah tahun lainnya.

\section{SIMPULAN}

Berdasarkan hasil analisis dan pembahasan pada bab sebelumnya, maka dapat disimpulkan sebagai berikut:

1. Berdasarkan hasil metode rasio informasi kinerja reksadana saham syariah pada tahun 2015 hingga 2017 menunjukkan bahwa terdapat perbedaan yang signifikan antara kinerja reksa dana syariah tahun 2015 sampai dengan setelah diuji dengan uji statistik menggunakan Uji One-way Anova. Perbedaan kinerja reksadana saham syariah tersebut setelah di analisis dengan Uji Tukey mendapatkan hasil bahwa kinerja tahun 2017 berbeda signifikan jika dibandingkan dengan kinerja reksadana saham syariah tahun 2015 dan 2016. Sedangkan, pada tahun 2015 dan 2016 kinerja reksadana saham menunjukkan hasil perbedaan yang tidak signifikan atau tidak ada perbedaan kinerja pada 2015 dan 2016. Hal tersebut menunjukkan bahwa kinerja manajer investasi mengalami peningkatan dalam mengelola dan mengalokasikan sumber dana ke instrument-instrumen yang tepat sehingga memberikan hasil yang lebih baik.Investor yang lebih berani memilih risiko investasi yang lebih tinggi cocok menggunakan penghitungan kinerja Rasio Informasi dimana Rasio ini mengambil acuan benchmark yang dapat diperhitungkan investor supaya dapat memperoleh tingkat pengembalian yang maksimal.

2. Berdasarkan hasil metode Rasio Sortino kinerja reksadana saham syariah pada tahun 2015 hingga 2017 menunjukkan bahwa tidak terdapat perbedaan yang signifikan antara kinerja reksa dana syariah tahun 2015 sampai dengan setelah diuji dengan uji statistik menggunakan Uji One-way Anova. Hal tersebut menunjukkan bahwa kinerja manajer investasi tidak mengalami perubahan baik peningkatan ataupun penurunan kinerja dalam mengelola dan mengalokasikan sumber dana ke instrument-instrumen yang tepat 
Azis, et al/Jurnal Ekonomi Syariah Teori dan Terapan Vol. 6 No. 8 Agustus 2019: 1644-1659; PENGUKURAN METODE RASIO INFORMASI, RASIO SORTINO DAN ROY SAFETY FIRST RATIO PADA KINERJA REKSADANA SAHAM SYARIAH PERIODE 2015-2017

sehingga memberikan hasil yang tidak berbeda.Tipe investor yang menggunakan metode ini adalah tipe intermediateda akan terkesan pasif karena menunggu moment-moment tertentu dalam melangkah.

3. Berdasarkan hasil metode Roy Safety First Ratio kinerja reksadana saham syariah pada tahun 2015 hingga 2017 menunjukkan bahwa terdapat perbedaan yang signifikan antara kinerja reksa dana syariah tahun 2015 sampai dengan setelah diuji dengan uji statistik menggunakan Uji One-way Anova. Perbedaan kinerja reksadana saham syariah tersebut setelah di analisis dengan Uji Tukey mendapatkan hasil bahwa kinerja tahun 2015 hingga 2017 berbeda signifikan jika dibandingkan dengan kinerja reksadana saham syariah tiap tahunnya. Hal tersebut menunjukkan bahwa kinerja manajer investasi mengalami peningkatan dan penurunan dalam mengelola serta mengalokasikan sumber dana ke instrument-instrumen yang tepat sehingga memberikan pengaruh pada hasil. Investor yang mempunyai sikap enggan terhadap risiko atau risk-averse investors lebih baik disarankan menggunakan metode Roy Safety First Ratio karena pada metode pengukuran resiko suatu kinerja reksadana menjadi hal yang diapresiasi selain tingkat pengembalian reksadana. Metode Roy Safety First Ratio juga cocok bagi investor yang sudah berpengalaman dalam investasi yang dimana investor dapat membaca gejolak ekonomi suatu periode sehingga dapat menentukan return yang diinginkn dengan tepat.

4. Bagi peneliti selanjutnya berkaitan dengan penelitian lanjutan dimasa yang akan dating. Peneliti pada penelitian ini memiliki batasan batasan penelitian berdasarkan periode penelitian yaitu tahun 2015 2017, sampel data yang digunakan hanya pada reksadana saham syariah dan fokus yang digunakan pada penelitian ini adalah pengukuran kinerja reksadana saham syariah dengan metode Informasi, Metode Rasio Sortino dan Roy Safety First Ratio. Peneliti berpesan sebaiknya pada peneltian selanjutnya menggunakan periode data return bulanan yang diperoleh dari perhitungan nilai NAB harian reksadana diperpanjang. Dalam penelitian ini peneliti hanya mengambil reksadana saham syariah diharapkan untuk peneliti selanjutnya meneliti tentang jenis-jenis reksadana syariah lainnya. Dalam hasil penelitian lanjutan meneliti tentang kinerja reksadana menggunakan model yang lebih 
Azis, et al/Jurnal Ekonomi Syariah Teori dan Terapan Vol. 6 No. 8 Agustus 2019: 1644-1659; PENGUKURAN METODE RASIO INFORMASI, RASIO SORTINO DAN ROY SAFETY FIRST RATIO PADA KINERJA REKSADANA SAHAM SYARIAH PERIODE 2015-2017

kompleks seperti factor model atau model analysis.

\section{DAFTAR PUSTAKA}

Ahmadinia, hamed. 2012. Evaluation performance of 50 Top Companies Listed In Tehran stock Exchange By Sortino, erov And M3. International journal of economics And Finance. Vol. 4, No. 1; Januari 2012Anoraga, Panji dan Panji Pakarti. 2001. Pengantar Pasar Modal. Edisi Revisi. Jakarta: PT Rineka Cipta.

Halim, Abdul. 2005. Analisis Investasi. Edisi II. Jakarta: Salemba Empat

Hartono, Jogiyanto. 2007. Teori Portofolio dan Analisis Investasi Edisi 2007. Yogyakarta. BPFE.

Rudiyanto. 2013. Sukses Finansial Dengan Reksadana. jakarta: Elex Media
Komputindo.Hartono, Jogiyanto, 1998, Teori Portofolio dan Analisis Investasi. Edisi pertama. BPFE.Yogyakarta

Simforianus, Hutagaol, Tanthu. 2008. Analisis Kinerja Reksadana Saham Dengan Metode Raw Return, Sharpe, Treynor, dan Sortino. Journal of Applied Finance And Acounting Vol. 1 No.l November 2008: 193-226

Tandelilin, Eduardus. 2010. Portofolio dan Investasi Teori dan Aplikasi. Yogyakarta. BPFE

Widjaja, Gunawan dan Almira Prajna Ramaniya. 2006. Reksa Dana dan Peran Serta Tanggung Jawab Manajer Investasi dalam Pasar Modal. Jakarta:Kencana Prenada Media Group. 